slthough it developed at a later date and to a much lesser extent with nickel and iron; very slight growth was noted after treatment with mercury.

A detailed account of these observations will be sommunicated elsewhere.

School of Agriculture,

$$
\text { W. A. R. Dillon Weston. }
$$
R. Eric Taylor.

Cambridge.

Dec. 8.

\section{Effect of Parental Feeding on the Rate of Development and Mortality of Tribolium jestructor Uyttenboorgaart (Coleoptera, Tenebrionidæ)}

THE object of these experiments was to show the effect, on the rate of development and mortality of offspring, of feeding their parents on flour of different extractions. All experiments were carried out under the same conditions (apart from the food used), which were as follows :

Newly emerged first instar larvæ of Tribolium destructor (from eggs laid about 200 days after the first oviposition of the female) were put, in fours, in open 3 in. $\times 1$ in. glass tubes; in a dark incubator; at $25^{\circ} \mathrm{C} .\left( \pm \frac{1}{2} \mathrm{C}.\right)$; and at a humidity of 50-60 per cent R.H. (usually about 56 per cent R.H.).

The two kinds of flour used, 85 per cent (National Wheatmeal) and 60 per $\cdot$ cent (High Grade White Flour), were kindly provided by the Research Association of British Flour Millers, from a single sample of grain. The food was kept in the incubator, until it had reached equilibrium with the temperature and humidity, before being used; and an ample quantity (about $2 \mathrm{gm}$. per larva) was provided at the beginning of the experiments, for the full period of development, so contamination by fæces was negligible. The individuals were only examined at or near the pupal stage, and were treated very gently, 80 handling was inconsiderable.

In all experiments at least a hundred individuals were used, and no results, however extreme, were omitted in calculating the averages. The sexes were noted, but since they show no significant difference in length of period of development, males and females are not separated in the summaries. All figures given in the summaries show the average number of days taken from the emergence of the first instar from the egg to the eclosion of the adult from the pupa.

The mortality figures include all larval, prepupal and pupal deaths, but adult viability was not investigated. The experiments where parents were fed on 85 per cent flour, and their offspring fed on 60 per

RATE OF DEVELOPMENT

\begin{tabular}{|c|c|c|c|c|}
\hline & \multicolumn{2}{|c|}{$\begin{array}{c}\text { Parents fed on } \\
85 \%\end{array}$} & \multicolumn{2}{|c|}{$\begin{array}{c}\text { Parents fed on } \\
60 \%\end{array}$} \\
\hline & Average & $\begin{array}{l}\text { Standard } \\
\text { Deviation }\end{array}$ & Average & $\begin{array}{r}\text { Standard } \\
\text { Deviation }\end{array}$ \\
\hline Larv $\gg$ reared on $60 \%$ & $44 \cdot 4$ & $\pm 2 \cdot 4$ & $52 \cdot 4$ & $\pm 5 \cdot 3$ \\
\hline Larvæ reared on $85 \%$ & $43 \cdot 9$ & $\pm 1 \cdot 7$ & $48 \cdot 2$ & $\pm 3 \cdot 8$ \\
\hline
\end{tabular}

\begin{tabular}{|ll|r|r|}
\hline \multicolumn{2}{|c|}{ Montautrx } \\
\hline Parents fed on .... & $\ldots .$. & $85 \%$ & $60 \%$ \\
\hline Larvæ fed on $85 \%$ & $\ldots .$. & $\begin{array}{r}7 \% \\
14 \%\end{array}$ & $\begin{array}{l}39 \% \\
41 \%\end{array}$ \\
\hline
\end{tabular}

cent flour, were repeated as a check and it will be seen that the results (average 44.9 ; standard deviation $2 \cdot 1$; mortality 3 per cent) approximate very closely to those obtained in the original experiment.

The results show that the rate of development of the offspring is influenced by the food on which their parents are fed. Thus, whether larvæ are fed on 60 per cent flour or on 85 per cent flour, they develop more rapidly when their parents have been fed on 85 per cent flour than when their parents have been fed on 60 per eent flour. Indeed, so strong is the effect of parental food that larvæ develop more quickly on 60 per cent flour, if their parents have been fed on 85 per cent flour, than they do on 85 per cent flour if their parents have been fed on 60 per cent flour. Applying Fisher's $t$ test to these results, the differences between larvæ fed on the same foods, but whose parents were fed differently, are highly significant $(P<0 \cdot 01)$. The difference between the larvæ which were fed on 60 per cent and 85 per cent (parents 60 per cent) is also significant $(P<0 \cdot 01)$. The difference between the larvæ whose parents were fed on 85 per cent is not significant ( $P$ between $0 \cdot 1$ and $0 \cdot 05$ ).

Similar conclusions are reached from a study of the mortality figures. These again show the advantage to the offspring of parents fed on 85 per cent flour, whether the offspring themselves be fed on 85 per cent or 60 per cent flour. The figures also show that the food of the parent has a greater effect on mortality than has the food of the larvæ.

These experiments are part of some work done voluntarily for the Pest Infestation Laboratory of the Department of Scientific and Industrial Research, and I wish to express my thanks to Mr. G. V. B. Herford and Dr. O. W. Richards for their readiness at all times to give help and advice.
Biology Department, J. M. REYNOLDS.
College of Technology, Leicester.

Nov. 19.

\section{Discoveries by Accident}

Prof. Russ will find it interesting, I think, to refer to the 1929 May Lecture of the Institute of Metals which was delivered by Sir Oliver Lodge on the theme of "States of Mind which Make and Miss Discoveries".

"It is instructive," said Sir Oliver Lodge, "to realise the state of mind which misses a discovery as well as, what is more commonly attended to, the more admirable state of mind which succeeds." Many experimenters had opportunities as good as Röntgen's to observe the X-rays which were generated in their laboratories. Sir Oliver Lodge cited the case of Rev. Frederick Smith who, on finding that the plates wrapped in a box near a tube were fogged, was - so to speak - annoyed at this disturbance of his experiments, and kept the plates out of the way.

I have always remembered the fascinating manner in which Sir Oliver Lodge elaborated the philosophy of the inventive mind in this lecture; and I have remained convinced that the "admirable state of mind" which led Röntgen to follow up his observation fully entitles him to recognition as the discoverer of $X$-rays.

Johnson, Matthey and Co., Ltd.,

Research Laboratories,

Exhibition Grounds, Wembley. 